Horn, P. et al. (2011). Factors explaining the academic success of second-year economics students: an exploratory analysis.

South African Journal of Economics, 79(2): 202 - 210.

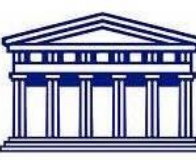

UNIVERSITY of the

WESTERN CAPE

\title{
Factors explaining the academic success of second-year economics students: an exploratory analysis
}

\author{
Petronella Horn, Ada Jansen and Derek Yu
}

\begin{abstract}
Factors influencing the academic success of first-year economics students have been intensely researched. Lecture and tutorial attendance, age, gender, as well as matriculation results have been identified as significant in explaining academic performance. The academic success of senior students, however, has received less attention in South Africa. This paper presents the findings of an investigation into the academic performance of secondyear economics students at Stellenbosch University. Using a Heckman two-step model, the study analyses whether the factors explaining first-year academic success are applicable in the second year or if other factors are relevant. The results suggest that most matriculation subjects become statistically insignificant for second-year students, whereas lecture and tutorial attendance remain important contributors to academic success. Furthermore, academic performance in the first year is an important determinant of success in the second year.
\end{abstract}

\section{Introduction}

Factors influencing the academic success of first-year economics students have received a great deal of attention from South African researchers. ${ }^{1}$ The motivation behind some of these studies was to investigate the reasons for the poor performance in economics at university. Their findings reflected that academic success depends on factors such as matriculation $^{2}$ results, lecture and tutorial attendance, age and gender. A positive correlation was found between students' academic performance and Higher Grade (HG) mathematics, as well as the aggregate matriculation mark. ${ }^{3}$ This positive relationship also exists between lecture and tutorial attendance and academic performance. 4

An important question is whether the academic performance of senior economics students can be predicted by similar factors as those influencing first-year students, or whether other factors are relatively more significant. Little empirical research, however, has been

\footnotetext{
${ }^{1}$ See Edwards (2000), Van Walbeek (2004), Parker (2006), Van der Merwe (2006), Smith and Edwards (2007), Horn and Jansen (2009) and Smith (2009).

${ }^{2}$ Matriculation refers to the final year of study at secondary school. The results of this examination usually determine entrance to university. Throughout the rest of the paper, the two terms "matriculation" and "Matric" will be used interchangeably.

${ }^{3}$ See Van Walbeek (2004), Horn and Jansen (2009) and Smith (2009).

${ }^{4}$ See Romer (1993), Kirby and McElroy (2003), Van Walbeek (2004), Horn and Jansen (2009) and Smith (2009).
} 
done on senior economics students in South Africa. ${ }^{5}$ At the international level, ${ }^{6}$ Graunke and Woosley (2005:367) indicate that college sophomores (second-year students) 7 may face academic difficulties. According to Pattengale and Schreiner (2000), as quoted in Graunke and Woosley (2005:367), the sophomore year is when students disengage themselves from academic life, which might negatively affect their academic performance. In his investigation of sophomores, Gump (2007) found that second-year students performed better than first-year students in a specific elective course taken by both groups. Sophomores outperformed both first- and third-year students, as they are more likely to attend classes. The importance of second-year lecture attendance is also supported by Friedman et al. (2001).

Gahagan and Hunter (2006), as well as Flowers (2002), argued that second-year students are aware of the importance of their performance in a potential major subject and may therefore be more goal orientated than freshmen. In addition, Friedman et al. (2001) found that second-year students who stay in the campus residences do not attend classes more often than commuting students. This is supported by Blimling (1999), who indicated that, in general, students living in university residences do not necessarily perform better. In a more recent study by Cheesman et al. (2006), there is evidence that students in residences outperformed those students who are commuting, which supports the study by Hountras and Brandt (1970).

An issue that potentially affects sophomore performance is that they do not receive the same institutional support (e.g. faculty interaction within and outside the traditional academic environment, curriculum advice and career guidance) that freshmen do, even though it could be more applicable to them in the attainment of their goal (Graunke and Woosley, 2005). Gahagan and Hunter (2006) support this and indicated that institutions should pay greater heed to the specific needs of sophomores.

This study aims to add to the local literature that investigates outcomes in higher education. It attempts to explore which factors influence the academic success of senior students. The case study used is the 2008 performance of second-year economics students at Stellenbosch University (SU), a South African university in the Western Cape. The outline of the paper is as follows: Section 2 provides some information on the second-year economics modules at SU, outlining the content, assessment opportunities and composition of the economics module under investigation. This is followed by Section 3, which discusses the data used in the descriptive and econometric analysis. A particular focus is on the students' matriculation attainment, study characteristics and their academic performance in the first and second year of economics. Section 4 discusses the econometric model and results. Section 5 concludes the paper.

\footnotetext{
${ }^{5}$ An exception is a study by Smith and Edwards (2007).

${ }^{6}$ The studies mentioned do not investigate the academic performance of senior economics students.

7 The US literature uses this term to refer to students in their second year of study even if they attend introductory courses in their second year, as part of the requirements for their qualification.
} 


\section{The second-year economics modules at SU}

Second-year Economics is an elective subject at SU. The Economics Department offers two second-year modules, namely Economics 214 (ECO214) and Economics 244 (ECO244). The former includes the core economic theory, namely Microeconomics and Macroeconomics, while ECO244 focuses on Monetary Policy, International Trade and Finance. These modules are offered in the first and second semesters, respectively. This paper relates to ECO214.

In 2008, 574 students were enrolled for the $\mathrm{ECO} 214$ module. There were 39 lecture periods and nine voluntary tutorial sessions. ${ }^{8}$ Eight roll calls were taken during the semester to record lecture attendance. Furthermore, roll calls were taken for all tutorial sessions. Students could also use online learning (the WebCT Vista system) to access information on the module, download course material and interact with other students. The assessment consisted of four tests, an essay and an examination. Students had to write any three of the four tests, but they could also opt to write all four tests in an attempt to improve their course mark. 9 The course mark was calculated as a weighted average of the test marks and the essay mark.

Students who did not comply with the course requirements (i.e. they did not write at least three tests, did not submit the essay or the course mark was below 40\%) were not allowed to write the examination. There are two examinations which comprised of essay-type questions. ${ }^{10}$ The final mark was the weighted average of the course mark and the examination mark.

\section{Data}

This section discusses the data used in the empirical analysis. The data were obtained from the university's student administration database. It contains information on the demographic characteristics of the students and their educational attainment. From the sample of 574 students, four students were excluded because they did fewer than six Matric subjects, while another 18 students completed their first-year Economics at other tertiary institutions. Furthermore, the Matric performance by subject was not available for 13 students. Hence, the final sample used is 539 students.

The majority of the ECO214 students are South Africans (97.2\%). Nearly two-thirds of them resided in the Western Cape at the time of the study. Approximately $87.6 \%$ of the class was White, $8.5 \%$ was Coloured, $3.5 \%$ was Black and $0.4 \%$ was Indian. Two-thirds of the class was male, while more than $70 \%$ of the students were between 19 and 20 years during the study period.

\footnotetext{
${ }^{8}$ Tutorial attendance became compulsory in 2009.

${ }^{9}$ Some students wrote the fourth test because they were absent in one of the first three tests for reasons such as illness and timetable clashes. Twenty-five students wrote all four tests because they wanted to improve their course mark.

${ }^{10}$ Only students who were absent from the first examination (exam1) due to valid reasons as well as students whose final mark was a fail (after exam1) were allowed to write the second examination. However, since 2009 students have the option of writing either examination.
} 
Table 1. Matriculation results of the students by subject

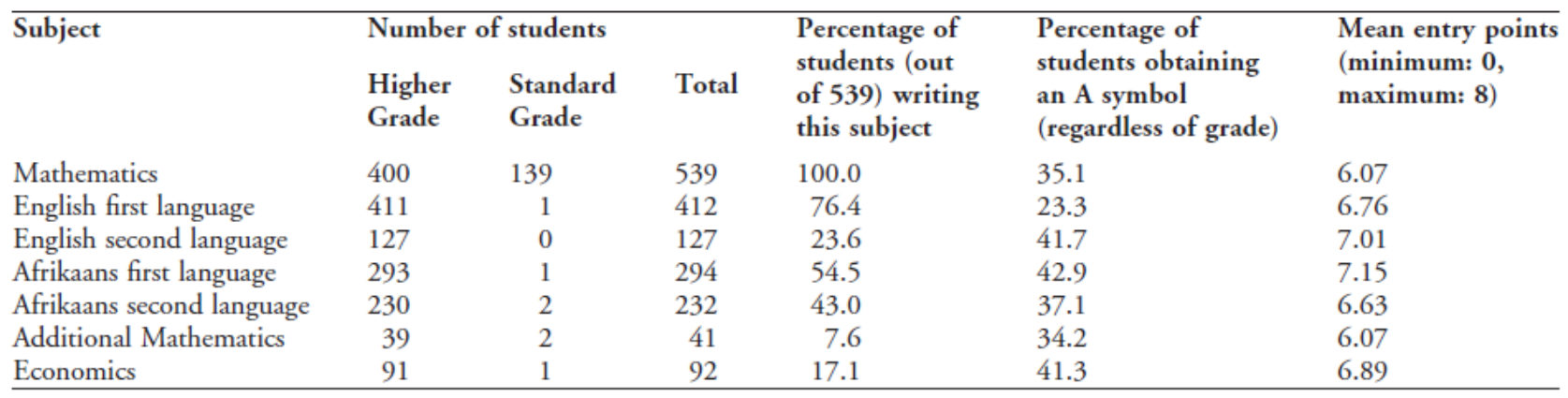

In terms of their matriculation study characteristics, $56.4 \%$ of the students matriculated at schools affiliated to the Western Cape Education Department, whereas 18.0\% matriculated from schools under the Independent Education Board. The remainder matriculated from other provincial education departments. Table 1 presents the students' performance of selected Matric subjects. It indicates that $35.1 \%$ of students obtained an A symbol (i.e. a final mark of $80 \%$ or above) in Mathematics, regardless of grade. Nearly three quarters of the students did English first language, with only a quarter of these students obtaining an A symbol. In contrast, $54.5 \%$ of the students did Afrikaans first language and $42.9 \%$ of them obtained a distinction. Furthermore, only $7.6 \%$ and $17.1 \%$ of the students did Additional Mathematics and Economics, respectively. Finally, the mean matriculation entry point ${ }^{11}$ was 39.8 , with slightly more than half of the students scoring an entry point of 40 or above.

Table 2 illustrates the first- and second-year academic characteristics of the students. Eightytwo point four percent of them were enrolled for a bachelor's degree in the Faculty of Commerce. Nearly half of the students stayed in university residences, while approximately $10 \%$ lived with their families. The remaining students resided in private accommodation.

With regard to students' performance in first-year Economics (i.e. the ECO178 module), approximately $10 \%$ of the students passed first-year Economics after attending summer school. ${ }^{12}$ Only $7.8 \%$ obtained a distinction (i.e. $75 \%$ or above).

As far as the $\mathrm{ECO} 214$ registration status was concerned, nearly $85 \%$ of the students enrolled for the first time in 2008. With regard to lecture and tutorial attendance, nearly $10 \%$ of the students attended all lectures recorded and $4 \%$ of the students attended all tutorials. The

\footnotetext{
11 This paper adopts the same entry point award system as is used at the University of Cape Town, as described by Van Walbeek (2004). A declining scale was used to award points for each symbol obtained. If the subject was taken on HG, 8 points were awarded for an A symbol, 7 points were awarded for a B symbol, and so forth. For Standard Grade (SG), 6 points were awarded for an A symbol, 5 points were awarded for a B symbol, and so forth. Students who obtained a $\mathrm{G}$ symbol were not awarded any points, regardless of the grade. The maximum total entry points awarded for six subjects (i.e. English, Mathematics and the best four other subjects) was 48 points. If a student took a language subject as second language, the entry points were reduced by $25 \%$ for comparability purposes. For example, if a student obtained an A symbol in Afrikaans second language HG, the entry point would be 6 points $(8 ¥ 75 \%)$.

12 The summer school was introduced in the 2007 academic year. Students who failed the ECO178 examination were given the opportunity to repeat the module in the summer school.
} 
ECO214 performance indicates that $92.8 \%$ of the students qualified to write the examination, with $87.4 \%$ of these students eventually writing exam1.

Table 2. Academic characteristics of the ECO214 students

\begin{tabular}{|c|c|c|}
\hline & $\begin{array}{l}\text { Number of } \\
\text { students }\end{array}$ & $\begin{array}{l}\text { Percentage } \\
\text { of students }\end{array}$ \\
\hline \multicolumn{3}{|l|}{ Faculty } \\
\hline Agriculture & 6 & 1.1 \\
\hline Arts & 83 & 15.4 \\
\hline Commerce - Actuarial Science & 27 & 5.0 \\
\hline Commerce - Non-Actuarial Science & 417 & 77.4 \\
\hline \multirow[t]{2}{*}{ Law } & 6 & 1.1 \\
\hline & 539 & 100.0 \\
\hline \multicolumn{3}{|l|}{ Residence status } \\
\hline University residence & 251 & 46.6 \\
\hline University house & 4 & 0.7 \\
\hline Private accommodation & 208 & 38.6 \\
\hline Private hostel & 11 & 2.0 \\
\hline Living with family & 58 & 10.8 \\
\hline \multirow[t]{2}{*}{ Others } & 7 & 1.3 \\
\hline & 539 & 100.0 \\
\hline \multicolumn{3}{|c|}{ ECO178 final mark, before summer school } \\
\hline $0-49 \%$ & 53 & 9.8 \\
\hline $50-54 \%$ & 238 & 44.2 \\
\hline $55-59 \%$ & 70 & 13.0 \\
\hline $60-64 \%$ & 74 & 13.7 \\
\hline $65-69 \%$ & 42 & 7.8 \\
\hline $70-74 \%$ & 20 & 3.7 \\
\hline \multirow{2}{*}{$75-100 \%$} & 42 & 7.8 \\
\hline & 539 & 100.0 \\
\hline \multicolumn{3}{|l|}{ ECO214 lecture attendance } \\
\hline 0 & 33 & 6.1 \\
\hline $1-2$ & 97 & 18.0 \\
\hline $3-4$ & 103 & 19.1 \\
\hline $5-7$ & 251 & 46.6 \\
\hline \multirow[t]{2}{*}{8} & 55 & 10.2 \\
\hline & 539 & 100.0 \\
\hline Mean & 4.56 & \\
\hline \multicolumn{3}{|l|}{ ECO214 tutorial attendance } \\
\hline 0 & 106 & 19.7 \\
\hline $1-2$ & 131 & 24.3 \\
\hline $3-4$ & 126 & 23.4 \\
\hline $5-6$ & 95 & 17.6 \\
\hline $7-8$ & 60 & 11.1 \\
\hline \multirow[t]{2}{*}{9} & 21 & 3.9 \\
\hline & 539 & 100.0 \\
\hline Mean & 3.31 & \\
\hline \multicolumn{3}{|l|}{ ECO214 exam1 mark } \\
\hline Did not qualify to write examination & 39 & 7.2 \\
\hline Qualified but did not write exam1 & 29 & 5.4 \\
\hline \multirow{2}{*}{ Qualified and wrote exam 1} & 471 & 87.4 \\
\hline & 539 & 100.0 \\
\hline
\end{tabular}




\section{Econometric analysis and results}

The educational production function approach (Hanushek, 1979; Siegfried and Fels, 1979) can be used to determine which inputs are relevant in explaining output (i.e. academic performance). Using this approach, an econometric analysis was conducted to investigate which factors influence students' performance in exam1.

Because some students did not qualify to write the examination, the results of an Ordinary Least Squares regression model would be biased due to sample selection problems. For this reason, a Heckman two-step model was applied. In the first step, a probit analysis was used to identify the factors determining the students' likelihood of writing the examination. The second step analysed the factors influencing their performance in the examination.

The explanatory variables used were based on previous empirical research. ${ }^{13}$ One of the variables considered to influence the likelihood of qualifying to write the examination was the results of the first test (Smith, 2009:167), since students who performed well in this test (test1) were more likely to qualify and write the exam1. As seven students did not write test1, an interaction variable was calculated to include them as part of the sample. In the case of these students, a mark of zero was awarded for test1. The interaction variable was equal to the product of this revised test1 mark and a dummy variable that indicated whether the students wrote test1.

Empirical findings (Van Walbeek, 2004; Horn and Jansen, 2009) indicated that students who attended tutorials and lectures more often performed relatively better. It was also argued that age, gender and race could have an influence on students' likelihood of writing the examination (Smith, 2009:168). Age in years was included as a continuous variable, whereas gender and raceweredummyvariables, with femaleand Indian/White ${ }^{14}$ students as the reference groups, respectively.

The education department of the school from where the students matriculated was included to account for the differences in Matric performance by education department. Since empirical evidence (Smith, 2009) suggest that students who did Matric Economics were more likely to write the examination, a dummy variable indicating students with Matric Economics was also included.

In the second step of the model, i.e. explaining students' performance in exam1, apart from the interaction variable, all the variables used in the first step were included as explanatory variables. Other variables considered were matriculation subject variables other than Economics, the Matric aggregate mark, ${ }^{15}$ faculty registration (the reference group is Commerce students not majoring in Actuarial Science), a dummy variable that indicated the students enrolled for ECO214 at least twice, the ECO178 final mark before summer school and a

\footnotetext{
${ }^{13}$ See Edwards (2000), Van Walbeek (2004), Van der Merwe (2006), Parker (2006), Smith and Edwards (2007), Horn and Jansen (2009) and Smith (2009).

${ }^{14}$ Due to the small sample size of the Indian students, they are added to reference group, i.e. the White students.

15 This is the aggregate mark of the best four subjects' entry points other than English and Mathematics.
} 
dummy variable that indicated whether students passed the latter module only after attending the summer school. The Heckman two-step regression results are shown in Table 3 .

The results of the first step indicate that older students are less likely to qualify to write the examination, which contradicts the findings of Van Walbeek (2004), Parker (2006), as well as Horn and Jansen (2009). However, the result is statistically insignificant. Male students have a greater likelihood of writing the examination, but once again, the result is statistically insignificant. In terms of race, Coloured students are less likely to qualify to write the examination, whereas Black students perform relatively better as compared to the reference group. However, only the former finding is statistically significant.

Tutorial attendance contributes positively and significantly to the likelihood of writing the examination but lecture attendance does not, with the former having a greater coefficient. This could be explained by the fact that tutorials contribute to a higher course mark. 
Table 3. Heckman two-step regression on the ECO214

exam1 mark

\section{Selection equation: Qualified for examination and wrote exam1}

$\begin{array}{ll}\text { Lecture attendance } & 0.05\end{array}$

Tutorial attendance $\quad 0.07^{*}$

Matriculation subject: Economics $\quad-0.34^{*}$

Interaction variable: Dummy variable: Wrote test $1 \times$ revised test 1 mark $\quad 0.03^{\text {*** }}$

Dummy variable: Black $\quad 0.46$

Dummy variable: Coloured $\quad-0.56^{* * *}$

$\begin{array}{lr}\text { Dummy variable: Male } & 0.05\end{array}$

Age in years $\quad-0.41$

Dummy variable: Matriculation examination department - Other than $\quad-0.21$ Western Cape

$\begin{array}{ll}\text { Constant } & 0.61\end{array}$

Exam1 mark

Dummy variable: Black $\quad-6.98^{* *}$

Dummy variable: Coloured $\quad 0.92$

Dummy variable: Male $\quad-1.28$

$\begin{array}{lr}\text { Age in years } & 0.59\end{array}$

Dummy variable: Staying in university residences $\quad 1.83$

Dummy variable: Faculty - Agriculture $\quad-0.29$

Dummy variable: Faculty - Arts $\quad-2.99^{*}$

Dummy variable: Faculty - Law $\quad-8.77$

Dummy variable: Faculty - Commerce (Actuarial Science) $\quad-3.34$

$\begin{array}{ll}\text { Lecture attendance } & 0.75^{*}\end{array}$

$\begin{array}{ll}\text { Tutorial attendance } & 0.29\end{array}$

ECO178 final mark before summer school $\quad 0.78^{* * * *}$

Dummy variable: Attended ECO178 summer school $\quad 5.49^{* * *}$

Dummy variable: Registered for ECO214 module at least twice $\quad-0.32$

Matriculation aggregate marks (Best four subjects, excluding English $\quad-1.54$ and Mathematics)

$\begin{array}{ll}\text { Matriculation aggregate marks squared } & 0.04\end{array}$

Dummy variable: Matric Additional Mathematics $\quad 3.67$

Dummy variable: Matric Economics $\quad-1.35$

Matriculation subject: Mathematics entry point $\quad 0.13$

Matriculation subject: English entry point $\quad-1.14^{*}$

Matriculation subject: Afrikaans entry point $\quad-0.56$

Dummy variable: Did not do Matric Afrikaans $\quad-5.17$

Dummy variable: Matriculation examination department - Other than $\quad 0.56$ Western Cape

$\begin{array}{lr}\text { Constant } & 15.23\end{array}$

Lambda $\quad-10.01^{\text {*** }}$

$\begin{array}{ll}\text { Chi-squared } & 204.88\end{array}$

R-squared $\quad 0.36$

Adjusted R-squared $\quad 0.33$

Number of observations $\quad 539$

* Significant at $10 \%$.

** Significant at 5\%.

*** Significant at $1 \%$. 
With regard to the matriculation characteristics, those students who did Economics were less likely to write the examination, and the result is statistically significant. This contrasts the findings of Van Walbeek (2004) and Smith (2009) in their studies on first-year performance. Furthermore, students matriculating from schools in education departments other than the Western Cape are less likely to write the examination.

When considering students' test1 performance, those who performed relatively better in this test are more likely to write the examination. This result is statistically significant and is similar to the findings of Smith (2009).

The second step indicates that age and gender are once again statistically insignificant, although older students now perform relatively better, while male students perform worse. With regard to race, Black students' exam1 marks are significantly lower by nearly 7 percentage points, as compared to the reference group. This result is supported by Van Walbeek (2004), Parker (2006) and Smith (2009).

Students in the university residences perform better in the examination. This could be explained by the fact that students on campus save time by not having to travel to and from campus, having access to learning and study facilities after hours and enjoying the benefit of connecting with their peers (Cheesman et al., 2006). However, the result is statistically insignificant.

With regard to the faculty dummy variables, all students performed worse than the reference group. This result is expected since students from outside of the Commerce faculty are likely to perform worse (Van Walbeek, 2004). However, only the Arts faculty dummy variable is statistically significant. The negative coefficient of the Actuarial Science dummy variable may seem surprising, but this could be due to the fact that other explanatory variables included in the second step have already captured the stronger ability of these students. Lecture attendance is positively significant while tutorial attendance is not, with the former having a greater coefficient. These results are opposite to the findings in the first step.

Students with a higher ECO178 final mark before attending summer school perform relatively better in the ECO214 exam1 mark. If the ECO178 final mark increases by 1 percentage point, the ECO214 exam1 mark improves by 0.78 percentage points. This result is statistically significant. Furthermore, students who passed ECO178 only after attending summer school obtain 5 percentage points more in the ECO214 exam1, as compared to the reference group. The positive sign of this coefficient is surprising since one expects that these students are academically weaker. This could be explained by the fact that other control variables such as race as well as tutorial and lecture attendance have already captured their weaker academic ability. Students who registered for ECO214 more than once perform relatively worse, but the result is statistically insignificant. 
With reference to the matriculation results, there is a positive non-linear relationship between the aggregate Matric mark from the best four subjects and the exam1 mark. This is consistent with the findings by Okpala et al. (2000), Van Walbeek (2004), Stanca (2006) and Horn and Jansen (2009) in their studies on first-year performance. However, this result is insignificant, suggesting that the matriculation results no longer play a significant role in explaining academic performance in the second year.

All the matriculation subject dummy variables are insignificant, except students with higher English entry points who perform significantly worse in exam1. These findings are somewhat different from the findings of the first-year studies where English, Mathematics and Additional Mathematics contribute positively and significantly to students' performance (Van Walbeek, 2004; Smith and Edwards, 2007; and Horn and Jansen, 2009). Finally, students who matriculated from schools outside the Western Cape Education Department perform better in exam1, but this result is statistically insignificant.

\section{Conclusion}

Many studies have looked at the academic success of first-year students. However, the local empirical literature pays less attention to second-year students. This paper investigated the academic performance of second-year economics students at SU. The primary goal was to explore whether the factors explaining the academic success in the first year still play a role in the second year or whether other factors are better predictors of their performance.

The study applied the Heckman two-step model and found that lecture and tutorial attendance contributed positively to academic success, which implies that academic support such as tutorials should form an integral part of the second-year Economics academic programme. An important finding was that matriculation results as a proxy of academic ability played a weaker role in explaining academic success in the second year, whereas performance in first-year Economics was a more important predictor. 


\section{References}

BLIMLING, G. S. (1999). A meta-analysis of the influence of college residence halls on academic performance. Journal of College Student Development, 40(5): 551-561.

CHEESMAN, J. S., SIMPSON, N. and WINT, G. (2006). Determinants of student performance at university: Reflections from the Caribbean. Available at: http://www.mona.uwi.edu/opair/research/student-performance-paper- $\quad$ revised.pdf [Accessed 2 August, 2009].

EDWARDS, L. (2000). An econometric evaluation of academic development programmes in economics. The South African Journal of Economics, 68(3): 455-483.

FLOWERS, L. A. (2002). Developing purpose in college: Differences between freshmen and seniors. College Student Journal, 36(3): 487-484.

FRIEDMAN, P., RODRIQUEZ, F. and MCCOMB, J. (2001). Why students do and do not attend classes. Myths and realities. College Teaching, 49(4): 124-133.

GAHAGAN, J. and HUNTER, M. S. (2006). The second year experience: Turning attention to the academy's middle children. About Campus, 11(3): 17-22. Available at: http://www3.interscience.wiley.com/journal/112729285/issue [Accessed 27 September 2008].

GRAUNKE, S. S. and WOOSLEY, S. A. (2005). An exploration of the factors that affect the academic success of college sophomores. College Student Journal, 39(2): 367-376.

GUMP, S. E. (2007). Classroom research in a general education course: Exploring implications through an investigation of the sophomore slump. The Journal of General Education, 56(2): 105-125.

HANUSHEK, E. (1979). Conceptual and empirical issues in the estimation of educational production function. The Journal of Human Resources, 14(3): 351-388.

HORN, P. and JANSEN, A. (2009). Tutorial classes - why bother? An investigation into the impact of tutorials on the performance of economics students. The South African Journal of Economics, 77(1): 179-189.

HOUNTRAS, P. T. and BRANDT, K. R. (1970). Relation of student residence to academic performance in college. The Journal of Educational Research, 63(8): 351-354.

KIRBY, A. and MCELROY, B. (2003). The effect of attendance on grade for first-year economic students in University College Cork. The Economic and Social Review, 34(3): 311326.

OKPALA, A., OKPALA, C. and ELLIS, R. (2000). Academic effort and study habits among students in a principles of macroeconomics course. Journal of Education for Business, 75(4): 219-224.

PARKER, K. (2006). The effect of student characteristics on achievement in introductory microeconomics in South Africa.

The South African Journal of Economics, 74(1): 137-149.

ROMER, D. (1993). Do students go to class? Should they? Journal of Economic Perspectives, 4(3): 167-174. SIEGFRIED, J. J. and FELS, R. (1979). Research on teaching college Economics: A survey. Journal of Economic Literature, 17(3): 923-969.

SMITH, L. C. (2009). An analysis of the impact of pedagogic interventions in first year academic development and mainstream courses in microeconomics. The South African Journal of Economics, 77(1): 162-178. 
-- - and EDWARDS, L. (2007). A multivariate evaluation of mainstream and academic development courses in first-year microeconomics. The South African Journal of Economics, 75(1): 99-117.

STANCA, L. (2006). The effects of attendance on academic performance: Panel data evidence for introductory microeconomics. Journal of Economic Education, 37(3): 251-266.

VAN DER MERWE, A. (2006). Identifying some constraints in first year economics teaching and learning at a typical South African university of learning. The South African Journal of Economics, 74(1): 150-159.

VAN WALBEEK, C. (2004). Does lecture attendance matter? Some observations from a first year economics course at the University of Cape Town. The South African Journal of Economics, 72(4): 861-883. 